\title{
Characterization of Hempseed Protein in Cheungsam from Korea
}

\author{
Jum-Ji Kim ${ }^{1}$ and Mi-Young Lee ${ }^{1 *}$ \\ ${ }^{1}$ Department of Medical Biotechnology, Soonchunhyang University \\ 한국산 청삼 헴프단백질의 특성 분석
}

\author{
김점지 ${ }^{1}$, 이미영 ${ }^{1 *}$ \\ ${ }^{1}$ 순천향대학교 의료생명공학과
}

\begin{abstract}
The neutrichemical analysis of hempseed from Cheungsam was performed in order to apply hempseed to food industry. Cheungsam hempseed was mainly composed of crude fat $(30.52 \%)$ and protein $(30.02 \%)$. The hempseed fat contained about $88 \%$ of polyunsaturated fatty acids, and the omega- 6 to omega- 3 ratio was determined to be approximately 3:1. Hempseed from Cheungsam was rich in essential amino acids. Moreover, hempseed protein from Cheungsam, extracted by acid-base precipitation method, showed free radical scavenging activity. The results suggest that Cheungsam hempseed protein could be utilized as a superior source of protein nutrition.

요 약 한국산 청삼종자를 식품산업 분야에서 응용하기 위해서 청삼종자의 영양화학적 분석을 실시하였다. 청삼종자 는 약 $30.52 \%$ 의 지방과 $30.02 \%$ 의 단백질로 구성되어 있었다. 청삼종자 지방은 약 $88 \%$ 의 불포화지방산으로 구성되어 있었으며, 오메가-6와 오메가-3 지방산 함량의 비율이 약 3:1이었다. 또한 청삼종자는 높은 필수 아미노산 함량을 나 타내었다. 뿐만 아니라 산-염기 침전법으로 추출한 청삼종자 단백질은 자유라디칼 소거활성을 나타내었다. 이러한 결 과들은 청삼 헴프단백질이 우수한 단백질 공급원으로 사용될 수 있음을 보여준다.
\end{abstract}

Key Words : Hempseed, Cheungsam, Characterization, Protein, Nutrient

\section{Introduction}

Hemp (Cannabis sativa L.) is a widely cultivated plant with industrial importance for thousands of years by prehistoric humans, especially as an valuable source of food, fiber and medicine[1]. In addition to the medical potential of cannabinoids in the leaves and flowers of the plant itself, hempseed has been utilized in the human diet for thousand of years. However, the effects of dietary hempseed intake have yet to be fully understood, owing largely to the politics prohibiting its cultivation, although hempseed has been recognized for thousands of years as an excellent sources of nutrition[2]. Recently hempseed has been legally used as food for humans in both Canada and the United States[3]. Hempseed has also been utilized as a valuable food source for farm animal, fish and cattle[4].

Hempseed, produced as a byproduct during commercial utilization of hemp fibre, is known to be rich source of high quality oil and protein[3]. The hempseed oil was known to contain over $80 \%$ of polyunsaturated fatty acids. A variety of studies demonstrated that hempseed is perfectly balanced in regards to the ratio of the two essential fatty acids, named linoleic (omega-6) and a -linolenic acid (omega-3) acids for human nutrition[3,5]. Besides the nutritional value, the hempseed oil also has some potential health benefits, such as lowering of cholesterol level, reducing high blood pressure, and treating human atopic dermatitis[6].

Hempseed protein was known to mainly consist of 
high-quality storage protein, named edestin (globulin) and albumin. The edestin and albumin in the hempseed had superior essential amino acid composition and was easily digested[1,3,7].

In Korea, a new variety of non-drug fiber hemp, named "Cheungsam", was developed by crossing IH3 Netherland variety and Korea local variety. The new variety of "Cheungsam" is regarded as non-drug type hemp, with a low level of $\delta-9$ tetrahydrocannabinol (THC).

There are a few reports about hempseed protein to utilize them as a source of protein nutrition. The information on the hempseed protein in Cheungsam from Korea is not available. The objective of this work was to characterize the hempseed protein in Cheungsam from Korea. The neutrochemical and antioxidant properties of hempseed protein from Cheungsam were investigated.

\section{Materials and Methods}

\subsection{Hempseed preparation}

Dehulled hempseeds from non-drug fiber hemp, named "Cheungsam", were ground in liquid nitrogen and then dispersed in deionized water at low temperature of less than $35^{\circ} \mathrm{C}$.

\subsection{Amino acid analysis}

The amino acid composition of the hempseed protein samples was determined by an automatic amino acid analyzer (Waters M510, USA), using PICO, TAG column[1]. The determination was carried out at $37^{\circ} \mathrm{C}$, with the detection wavelength of $254 \mathrm{~nm}$ and flow rate of $1.0 \mathrm{ml}$ per min. The samples were hydrolyzed with $6 \mathrm{~N}$ $\mathrm{HCl}$ for $24 \mathrm{~h}$ at $110^{\circ} \mathrm{C}$ in sealed tube. The amino acid composition was reported as $\mathrm{mg} / 100 \mathrm{~g}$ hempseed.

\subsection{Preparation of hempseed protein}

The hempseed protein was extracted as follows. $1 \mathrm{~g}$ of hempseed flour was mixed with $100 \mathrm{ml}$ deionized water, and the mixture was adjusted to $\mathrm{pH} 10.0$ with $1.0 \mathrm{~N}$ $\mathrm{NaOH}$. After continuously stirring for $1 \mathrm{~h}$, the suspensions were centrifuged at $8,000 \mathrm{~g}$ for $30 \mathrm{~min}$ and the precipitates were discarded. The $\mathrm{pH}$ of the supernatant was adjusted to $\mathrm{pH} 5.0$ at $4^{\circ} \mathrm{C}$ with $1 \mathrm{~N} \mathrm{HCl}$, and the precipitates were collected by centrifugation. The precipitates were washed with pre-cooled deionized water, and dispersed in the deionized water. The dispersions were adjusted to $\mathrm{pH} 7.0$ with $1 \mathrm{~N} \mathrm{HCl}$, and then dialyzed at $4^{\circ} \mathrm{C}$.

\subsection{Sodium dodecyl sulfate polyacrylamide gel electrophoresis (SDS-PAGE)}

SDS-PAGE was conducted according to the discontinuous buffer system of Laemmli[8] at 5\% stacking gel and $12.5 \%$ separating gel using gel electrophoresis apparatus. The protein samples were directly dissolved in the sample buffer, namely $0.125 \mathrm{M}$ Tris- $\mathrm{HCl}$ buffer $(\mathrm{pH}$ 8.0) containing $0.1 \%(\mathrm{w} / \mathrm{v})$ SDS, $0.05 \%(\mathrm{w} / \mathrm{v})$ bromophenol blue, $30 \%(\mathrm{v} / \mathrm{v})$ glycerol and $5 \%(\mathrm{v} / \mathrm{v}) \beta$-mercaptoethanol (2-ME). The electrophoresis was run at $20 \mathrm{mM}$ in stacking gel and at $40 \mathrm{mM}$ in separating gel until the tracking dye reached the bottom of the gel. Before electrophoresis, the samples were heated at $100^{\circ} \mathrm{C}$ for 5 min. The SDS-PAGE under nonreducing condition was carried out as mentioned above, just using the samples dissolved in the sample buffer without the addition of 2-ME[7,9].

\subsection{Periodic acid-Schiff (PAS) staining for carbohydrate}

After finishing SDS-PAGE, gels were fixed overnight in $25 \%$ isopropanol, $10 \%$ acetic acid and $65 \%$ water. Gels were washed for $1 \mathrm{~h}$ in running water, soaked in $1 \%$ $\mathrm{NaIO}_{4}, 3 \%$ acetic acid for $1 \mathrm{~h}$ and then washed for $2 \mathrm{~h}$ in running water and twice for $0.5 \mathrm{~h}$ with distilled water. The gels were then stained for $2 \mathrm{~h}$ with Schiff's reagent prepared from Basic Fuchsin[10]. Excess Schiff's reagent was removed by soaking in $0.5 \%$ sodium metabisulphite. The gels were then soaked for two times $3 \mathrm{~h}$ in $7 \%$ acetic acid.

\subsection{DPPH radical scavenging activity}

The DPPH (1,1-diphenyl-2-picrylhydrazyl) radical scavenging activity was determined by the method described earlier[11]. $2 \mathrm{ml}$ of the sample solution was mixed with freshly prepared $2 \mathrm{ml}$ of $0.2 \mathrm{mM} \mathrm{DPPH}$ ethanolic solution and vortexed for about $10 \mathrm{sec}$. The 
resulting solution was then left to stand for $30 \mathrm{~min}$, prior to reading the absorbance at $517 \mathrm{~nm}$. A low absorbance at $517 \mathrm{~nm}$ indicates a high DPPH scavenging activity. Ethanol was used as a blank.

\subsection{Protein solubility}

Protein solubility was determined according to the method of Tomotake et al.[12], with a few modifications. Protein dispersions $(1 \mathrm{mg} / \mathrm{ml}, \mathrm{w} / \mathrm{v})$ were prepared in 0.01 $\mathrm{M}$ phosphate buffer adjusted to $\mathrm{pH}$ 2-10. To achieve desirable $\mathrm{pH}$ above 10 , the protein dispersion was adjusted directly using $1 \mathrm{~N} \mathrm{NaOH}$. For total soluble protein contents (control), the samples were solubilized in $0.1 \mathrm{~N} \mathrm{NaOH}$. The solubilized proteins were stirred at room temperatures for $1 \mathrm{~h}$, centrifuged at $8,000 \mathrm{~g}$ for 30 min, and filtered through filter paper. Protein contents of the filtrate were determined according to the Bradford method using bovine serum albumin as a standard [13] Each measurement was performed in triplicate.

\section{Results and Discussion}

\subsection{Neutrichemical analysis of hempseed from Cheungsam}

The contents of crude protein, crude fat, fatty acids (saturated and unsaturated) and two essential fatty acids (linoleic acid and linolenic acid) of hempseed from Cheungsam were indicated in Table 1 . The hempseed was mainly composed of crude protein $(30.02 \%)$ and crude fat $(30.52 \%)$. In addition, the hempseed fat contained about $88 \%$ of polyunsaturated fatty acids. Moreover, it was an exceptionally rich source of the two essential fatty acids such as linoleic acid (18:2 omega-6) and linolenic acid (18:3 omega-3).

[Table 1] Neutrichemical compositions of hempseed from Cheungsam

\begin{tabular}{ll}
\hline Constituents & Cheungsam Hempseed \\
\hline Crude protein & $32.02 \%$ \\
Crude fat & $32.52 \%$ \\
Saturated fatty acid & $3.65 \mathrm{~g} / 100 \mathrm{~g}$ \\
Unsaturated fatty acid & $28.87 \mathrm{~g} / 100 \mathrm{~g}$ \\
Linoleic acid & $180.52 \mathrm{mg} / \mathrm{g}$ \\
Linolenic acid & $59.03 \mathrm{mg} / \mathrm{g}$ \\
\hline
\end{tabular}

Other hempseeds were also reported to contain over $30 \%$ fat and about $25 \%$ protein, with considerable amounts of dietary fiber, vitamins and minerals[3]. As shown in Table 1, the omega- 6 to omega-3 ratio (n6/n3) of hempseed from Cheungsam was determined to be approximately $3: 1$, indicating an excellent ratio for human health.

\subsection{Amino acid composition of hempseed from Cheungsam}

The amino acid compositions of hempseed from Cheungsam were determined as shown in Table 2. The hempseed had higher levels of glutamic acid, aspartic acid and arginine, which are consistent with the previous reports of other hempseeds $[1,3,7,14]$. Hempseed protein has been reported to have good amounts of the sulfur-containing amino acids methionine and cysteine[15]. However, the sulfur-containing amino acids methionine and cysteine might be in some content destroyed due to the $\mathrm{HCl}$ - hydrolysis method used in this experiment.

[Table 2] Amino acid compositions of hempseed from Cheungsam

\begin{tabular}{ll}
\hline Amino acids & $\mathrm{mg} / 100 \mathrm{~g}$ hempseed \\
\hline Isoleucine* $^{*}$ & 1168.83 \\
Leucine* $^{*}$ & 2029.29 \\
Lysine* $^{*}$ & 1053.81 \\
Methionine* & 475.87 \\
Cysteine & 95.85 \\
Tyrosine & 691.13 \\
Phenylalanine* & 1369.67 \\
Threonine* & 1113.71 \\
Valine* & 1450.23 \\
Histidine* & 887.01 \\
Tryptophan* & 318.17 \\
Aspartic acid & 3271.25 \\
Glutamic acid & 6273.65 \\
Serine & 1602.9 \\
Glycine & 1402.41 \\
Arginine* & 3470.47 \\
Alanine & 1375.59 \\
Proline & 1229 \\
\hline
\end{tabular}

Asparagine, Glutamine : N.D

Essential amino acids are indicated by asterisk* 
Notably, hempseed from Cheungsam were rich in essential amino acids such as arginine isoleucine, leucine, lysine, threonine, valine, phenylalanine, histidine and methionine. Hempseed protein from Cheungsam had more essential amino acids than that from Finola hemp[3].

Moreover, it had high quality proteins in common with soy bean and rape through a direct comparison of amino acid compositions from egg white, soy bean, rape seed, potato and rice[3]. The results suggest that the hempseed from Cheungsam has superior essential amino acid composition and thus it might be used as a good source of protein nutrition. The results also indicated that hempseed has good profile of essential amino acids required for infants[16,17].

\subsection{SDS-PAGE profiles of hempseed}

\section{protein}

The hempseed protein was prepared at room temperature by using acid-base precipitation method[1] SDS-PAGE profiles of protein constituents in the presence and absence of 2-mercaptoethanol were presented in Fig. 1. Under reduced condition, there were three major kinds of protein constituents, corresponding to $36.4 \mathrm{kDa}, 20.4$ $\mathrm{kDa}$ and $18.3 \mathrm{kDa}$ Fig. 1A. In the absence of 2-ME, the major protein band of about $52.5 \mathrm{kDa}$ was found, probably suggesting that the disulfide bonds between proteins detected on the denatured gel will not be disrupted, and as the result, the protein bands would be in the form of different size. Hempseed proteins were reported to mainly consist of edestin and albumin, and edestin is composed of six identical subunits, and each subunit consists of acidic subunit and basic subunit linked by one disulfide bond. In the present study, the band about $36 \mathrm{kDa}$ was homogeneous, while the other heterogeneous bands mainly consisted of two bands of about 20 and $18 \mathrm{kDa}$ in hempseed protein from Cheungsam. From the molecular size and relative content, the major protein is assumed to be edestin[18,19].

Fig. 1B shows the glycoprotein staining for hempseed protein isolate with periodic acid-Schiff (PAS) staining. As shown in Fig. 1B, only the bands assumed as edestin were detected by PAS staining in reduced and unreduced conditions. These results suggest that the suspected edestin in hempseed protein from Cheungsam might contain carbohydrate moiety in the structure.

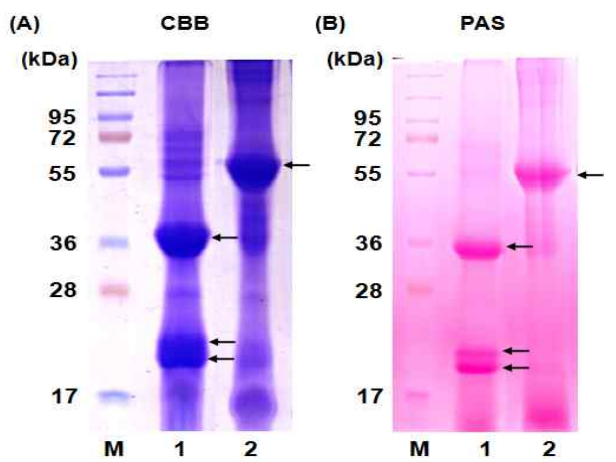

[Fig. 1] Coomassie brilliant blue (CBB) staining for protein (A) and periodic acid-Schiff (PAS) staining for carbohydrate (B) on the SDS-polyacrylamide gel for hempseed protein in the presence (reduced) and absence (unreduced) of $\beta$-mercaptoethanol. $\mathrm{M}$ : Molecular weight markers, 1: reduced condition, 2: unreduced condition

\subsection{DPPH free radical scavenging assay}

The DPPH free radical scavenging ability of hempseed protein was presented in Fig. 2. The stable DPPH radical in ethanol has been widely used to test the ability of some compounds to acts as free radical scavengers or hydrogen donors[10,20]. DPPH assay evaluates the ability of hempseed protein to scavenge free radicals of DPPH. The present DPPH assay showed that hempseed protein from Cheungsam possess free radical scavenging activity. The free radical scavenging ability of hempseed protein gradually increased with increasing protein concentrations Fig. 2. The $\mathrm{IC}_{50}$ value of the hempseed protein, meaning the concentration that causes a decrease in initial DPPH concentration by $50 \%$, was determined to be approximately $1.5 \mathrm{mg} / \mathrm{ml}$ as shown in Fig. 2. The $\mathrm{IC}_{50}$ value of wheat germ protein hydrolysate was $1.3 \mathrm{mg} / \mathrm{ml}$ and hempseed protein hydrolysate after hydrolysis using neutrase was reported to be 2.3-3.5 $\mathrm{mg} / \mathrm{ml}[4]$. The antioxidant properties of various food proteins, named bovine caseins[21], whey proteins[21], soy proteins[22-24], fish proteins[25,26] and wheat proteins[27] have been reported. The antioxidative ability of the food proteins could enlarge the application and utilization of food proteins for human nutrition. 


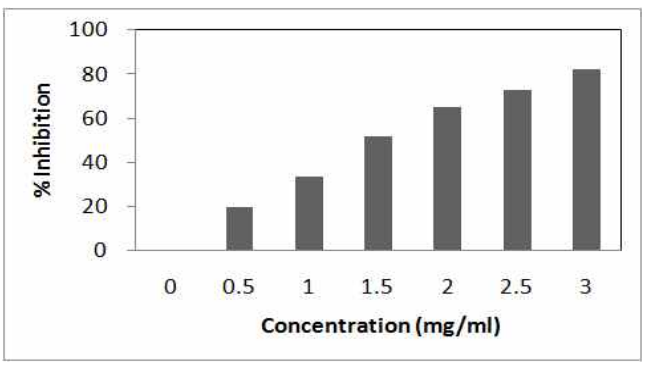

[Fig. 2] DPPH free radical scavenging activity of hempseed protein

\subsection{Solubility of hempseed protein}

Fig 3 shows the solubility of hempseed protein between $\mathrm{pH} 2$ and $\mathrm{pH} 10$. The protein solubility was minimum at $\mathrm{pH}$ in the range of 4.0-8.0 and increased gradually below $\mathrm{pH} 4.0$ and above $\mathrm{pH} 8.0$ Fig. 3. At $\mathrm{pH}$ 7.0 , only $10 \%$ of protein was solubilized in $0.01 \mathrm{M}$ phosphate buffer. However, at above $\mathrm{pH} 8.0$, the solubility increased up to more than $90 \%$. The data suggests that hempseed protein is a kind of typical alkali soluble protein. The underlying mechanism of solubilization at alkaline $\mathrm{pH}$ was reported to be related to the dissociation of edestin[28], while the low solubility at $\mathrm{pH}$ less than 7.0 might be due to the aggregation of edestin[29].

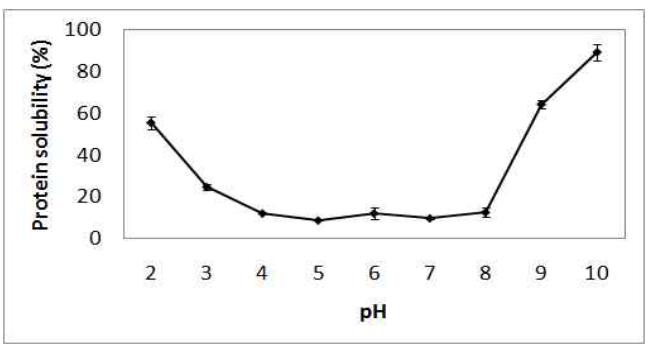

[Fig. 3] Protein solubility profile of hempseed protein from Cheungsam at different $\mathrm{pH}$ values.

The data obtained in this investigation implicate hempseed protein from Cheungsam as a prominent source of nutrients, which had good profiles of essential amino acids. Moreover, the omega- 6 to omega- 3 ratio of HPI was determined to be approximately $3: 1$, indicating an excellent ratio for human nutrition. Hempseed protein isolate was composed of a major component, probably edestin on the SDS-polyacrylamide gel, and it has a DPPH free radical scavenging ability. Taken together, hempseed protein from Cheungsam might be utilized as a superior source of protein nutrition, and it can be applied to food industry as a good source of nutrition.

\section{Acknowledgement}

This research was supported by Technology Development Program for Agriculture and Forestry, Ministry for Food, Agriculture, Forestry and Fisheries, Republic of Korea.

\section{References}

[1] X. S. Wang, C. H. Tang, X. Q. Yang, W. R. Gao, "Characterization, Amino Acid Composition and in vitro Digestibility of Hemp (Cannabis sativa L.) Proteins", Food Chem., 107, pp. 11-18, 2008.

[2] M. J. Lee, M. S. Park, S. Hwang, Y. K. Hong, G. Choi, Y. S. Suh, S. Y. Han, D. Kim, J. Jeun, C. T. Oh, S. J. Lee, S. J. Han, D. Kim D, E. S. Kim, G. Jeong, K. S. Cho, "Dietary Hempseed Meal Intake Increases Body Growth and Shortens the Larval Stage via the Upregulation of Cell Growth and Sterol Levels in Drosophila Melanogaster", Mol. Cells, 30, pp. 29-36, 2010.

[3] J. C. Callaway, "Hempseed as a Nutritional Resource: An Overview", Euphytica, 140, pp. 65-72, 2004.

[4] X. S. Wang, C. H. Tang, L. Chen, X. Q. Yang, "Characterization and Antioxidant Properties of Hemp Protein Hydrolysates Obtained with Neutrase", Food Technol. Boiotechnol., 47, pp 428-434, 2009.

[5] B. D. Oomah, M. Busson, D. V. Godfrey, J. C. G. Droper, "Characteristics of Hemp (Cannabis sativa L.) Seed Oil", Food chem., 76, pp. 33-43, 2002.

[6] J. Callaway, U. Schwab, I, Harvima, P. Halonen, O. Mykkänen, P. Havönen, T. Järvinen, "Efficacy of Dietary Hempseed Oil in Patients with Atopic Dermatitis", J. Dermatolog. Treat., 16, pp. 87-94, 2005.

[7] C. H. Tang, Z. Ten, X. S. Wang, X. Q. Yang, "Physicochemical and Functional Properties of Hemp (Cannabis sativa L.) Protein Isolate", J. Agric. Food Chem., 54, pp. 8945-8950, 2006.

[8] U. K. Laemmli, "Cleavage of Structural Proteins During the Assembly of the Head of the Bacteriophage T4", Nature, 227, pp. 680-685, 1970.

[9] J. J. Kim, Y. M. Jeon, J. H. Noh, M. Y. Lee, " Isolation 
and Characterization of a New Phycoerythrin from the Cyanobacterium Synechococcus sp. ECS-18", J. Appl. Phycol., 23, pp. 137-142, 2010.

[10] K. J. Clemetson, A. Capitanio, E. F. Lüscher, "High Resolution Two-dimensional Gel Electrophoresis of the Proteins and Glycoproteins of Human Blood Platelets and Platelet Membranes", Biochim. Biophys. Acta., 553, pp. 11-24, 1979.

[11] Y. N. Seo, J. J. Kim, K. S. Sung, M. Y. Lee, " Effect of Acanthopanax Extract on the DNA and Erythrocyte Damage Induced by Herbicides", J. Korean Soc. Appl. Biol. Chem., 11, pp. 4922-4927, 2010.

[12] H. Tomotake, I. Shimaoka, J. Kayashita, M. Nakajoh, N. Kato, "Physicochemical and Functional Properties of Buckwheat Protein Product", J. Agric. Food Chem., 50, pp. 2125-2129, 2002.

[13] M. M. Bradford, "A Rapid and Sensitive Method for the Quantitation of Microgram Quantities of Protein Utilizing the Principle of Protein-dye Binding", Anal. Biochem., 7, pp. 248-254, 1976.

[14] Y. Yang, W. Bai, "The Analysis of Amino Acid and Elements in Traditional Chinese Medicine Cannabis", Plant Fiber and Products (In Chinese), 23, pp. 17-19, 2001.

[15] S. Odani, S. Odani, "Isolation and Primary Structure of a Methionine and Cystine-rich Seed Protein of Cannabis sativa", Biosci. Biotechnol. Biochem., 62, pp. 650 -654, 1998.

[16] C. F. Chau, C. K. Cheung, Y. S. Wong, " Chemical Composition of Three Underutilized Legume Seeds Grown in China", Food Chem., 61, pp. 505-509, 1998.

[17] J. J. Doyle, M. A. Schuler, E. D. Godette, V. Zenger, R. N. Beachy, J. L. Slightom, " The Glycosylated Seed Storage Proteins of Glycine Max and Phaseolus Vulgaris. Structural Homologies of Genes and Proteins", J. Biol. Chem., 261, pp. 9228-9238, 1986.

[18] C. E. Hall, "Electron Microscopy of Crystalline Edestin", J. Biol. Chem., 185, pp. 45-51, 1950.

[19] T. M. Svedberg, A. J. Stamm, "The Molecular Weight of Edestin", J. Am. Chem. Soc., 51, pp. 2170-2185, 1929.

[20] C. L. Jao, W. C. Ko, "1,1-Diphenyl-2- picrylhydrazyl (DPPH) Radical Scavenging by Protein Hydrolysates from Tuna Cooking Juice", Fish. Sci., 68, pp. 430-435, 2002.

[21] A. Pihlanto, "Antioxidative Peptides Derived from Milk Proteins", Int. Dairy J., 16, pp. 1306-1314, 2006.

[22] H. M. Chen, K. Muramoto, F. Yamauchi, "Structural

Analysis of Antioxidative Peptides from Soybean $\beta$ -conglycinin", J. Agric. Food Chem., 43, pp. 574-578, 1995.

[23] H. M. Chen, K. Muramoto, F. Yamauchi, K. Fujimoto, K. Nokihara, "Antioxidative Properties of Histidine-containing Peptides Designed from Peptide Fragments Found in the Digests of a Soybean Protein", J. Agric. Food Chem., 46, pp. 49-53, 1998.

[24] A. Moure, H. Domínguez, J. C. Parazżo, "Antioxidant Properties of Ultrafiltration- recovered Soy Protein Fractions from Industrial Effluents and Their Hydrolysates", Proc. Biochem., 41, pp. 447-456, 2006.

[25] N. Rajapakse, E. Mendis, H. G. Byun, S. K. Kim, "Purification and in vitro Antioxidative Effects of Giant Squid Muscle Peptides on Free Radical-mediated Oxidative Systems", J. Nutr. Biochem., 16, pp. 562-569, 2005.

[26] S. Y. Kim, J. Y. Je, S. K. Kim, "Purification and Characterization of Antioxidant Peptide from Hoki (Johnius belengerii) Frame Protein by Gastrointestinal Digestion", J. Nutr. Biochem., 18, pp. 31-38, 2007.

[27] K, Zhu, H. Zhou, H. Qian, "Antioxidant and Free Radical-scavenging Activities of Wheat Germ Protein Hydrolysates (WGPH) Prepared with Alcalse", Proc. Biohem., 41, pp. 1296- 1302, 2006.

[28] D. A. Goring, P. Johnson, "The Preparation and Stability of Ultracentrifugally Monodisperse Edestin", Arch. Biochem. Biophys., 56, pp. 448-458, 1995.

[29] M. Friedman, D. L. Brandon, "Nutritional and Health Benefits of Soy Proteins", J. Agric, Food Chem., 49, pp. 1069-1089, 2001.

Mi-Young Lee

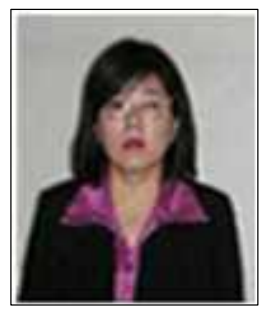

$<$ Research Interests $>$ Biotechnology

\section{[Regular member]}

- Feb. 1987 : Yonsei Univ., Biochem, MS

- Aug. 1991 : Yonsei Univ., Biochem, PhD

- Mar. $1992 \sim$ Current : Soonchunhyang Univ., Dept. of Medical Biotehcnology, Professor 
Jum-Ji Kim

[Regular member]

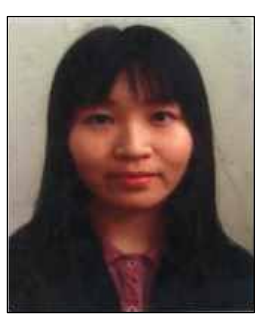

- Mar. $2011 \sim$ Current

Soonchunhyang Univ., Dept. of

Medical Biotechnology, PhD

$<$ Research Interests $>$

Biotechnology 